\title{
NOTES
}

\section{FAIR TRADE AND HORIZONTAL PRICE FIXING: THEIR STATUS SINCE THE SECOND SCHWEGMANN CASE*}

PRICE fixing systems are generally illegal per se under the federal antitrust laws, ${ }^{1}$ and, until 1937, this prohibition included systems whereby manufacturers fixed resale prices. ${ }^{2}$ In that year, however, Congress carved out an exception for trademarked or brand name goods. ${ }^{3}$ On such commodities manufacturers can, within limits, fix resale prices if permitted to do so by state law. ${ }^{*}$ In turn, the statutes of forty-five states allow price fixing agreements between manufacturer and retailer, ${ }^{5}$ and render them enforceable against

*Schwegmann Bros. Giant Super Markets v. Eli Lilly \& Ca., 205 F.2d 788 (5th Cir. 1953), cert. denied, 74 Sup. Ct. 71 (1953); In re Doubleday \& Co., CCH Tratue Re(3. REP. \ 11,515 (FTC 1953).

1. Sherman Act, 26 Stat. 209 (1890), 15 U.S.C. $\$ \$ 1-4$ (1946) ; Federal Trade Commission Act, 38 Stat. 717 (1914), 15 U.S.C. $\$ \$ 41-58$ (1946). E.g., Kiefer-Stewart Co. v. Joseph E. Seagram \& Sons, 340 U.S. 211 (1951); United States v. Socony-Vacuum Oil Co., 310 U.S. 150 (1940); United States v. Trenton Potteries Co., 273 U.S. 392 (1927).

Prior to the Fair Trade exception to be discussed in this Note, only patent and copyright holders were allowed to fix prices. United States v. General Electric Co., 272 U.S. 476 (1926). In recent years the Supreme Court has resisted efforts of patent holders to use this exception as a means of monopolizing an entire industry. United States v. United States Gypsum Co., 333 U.S. 364 (1948); United States v. Line Material Co., 333 U.S. 287 (1948). The Court has also prevented a copyright holder from fixing retail prices where it would tend to eliminate competition among retailers. United States v. Paramount Pictures, Inc., 334 U.S. 131 (1948). Similar attempts to limit Fair Trade price fixing have not yet been attempted. See note 37 infra.

2. Resale price maintenance systems establish minimum prices below which 110 dealer can sell. They were held illegal under both the Sherman Act, Dr. Miles Medical Co. v. John D. Park \& Sons Co., 220 U.S. 373 (1911), and the Federal Trade Commission Act, FTC v. Beech-Nut Packing Co., 257 U.S. 441 (1922).

3. This amendment was contained in the Miller-Tydings Act, 50 Stat. 693 (1937), 15 U.S.C. $\S 1$ (1946). It has been estimated that $50 \%$ of all market goods are identifiable by a trademark or brand name. Not all of the commodities are covered by Fair Trade systems; estimates of the percentage of sales where prices are fixed by Fair 'Trade agreements vary from $4 \%$ to $20 \%$. Cover, Problens of SMall Business 163, 199 (TNEC Monograph 17, 1941) (hereinafter cited as TNEC REpoRT) ; H.R. REP. No. 1292, 82d Cong., 2d Sess. 20 (1952).

4. The Miller-Tydings Act contained two limitations: the price-fixcd goods must be "in free and open competition" with commodities of the same general class; and the price-fixers may not be in a "horizontal" or competitive relationship, e.g., manufacturers and other manufacturers, jobbers and other jobbers, retailers and other retailers. However, Government antitrust agencies have maintained that these statutory limitations are extremely difficult to enforce. See notes 36-7 infra.

5. Fair Trade legislation exists today in all jurisdictions except Missouri, Texas, 
nonsigning retailers. ${ }^{6}$ This resale price maintenance system, operating under the deceptive misnomer "Fair Trade" 7 and defended as a necessary protection for small retailers, ${ }^{8}$ results in higher prices to the consumer. ${ }^{9}$

Vermont, and the District of Columbia. For table of state Fair Trade acts, see 5 C.uLmand, Unfair Conpetition and Trade-MLarks 2250 (1950). However, the statutes of Florida, Georgia, Michigan, and Tennessee have been rendered uneniorceable by judicial decision. See note 17 infra.

6. The nonsigner clause in each of the state acts provides that noncontracting retailers can be enjoined if, knowingly, they sell Fair Trade guuds below the fixed price. Most of these state acts label as "unfair competition" any attempt of the nonsigning retailer to sell for less than the fixed price. For example, the Louisiana Fair Trade Act provides:

"Wilfully and knowingly advertising, offering for sale or selling any commodity at less than the minimum price stipulated in any [Fair Trade] contract . . . sohether the person so . . selling is or is not a party to the contrat, is unfair competition and is actionable by any person damaged." 27 L.1. St.x. Axx. tit. 51, \$394 (1951) (emphasis added).

7. Fair Trade is hardly "fair" from the consumer's viewpoint because it fixes prices, eliminates competition, and deprives the public of the benefits of new distribution techniques. Nor is it "fair" to many nonsigning retailers, such as supermarliets, department stores, mail order houses, and "cut-rate," low overhead stores who desire to lower prices and specialize in quantity sales. Fair Trade forces them to sell at fixed, higher prices, and to share the profits with other, less efficient retailers. See TNEC RErest 196.

S. Fair Trade tends to perpetuate small retail stores in the Fair Trade industriesnotably the drug and liquor industries-because it prevents small retailers from being undersold by newer, more efficient retailing techniques. See Afund, Goirswaskst AND Business 448 (1950): Grether, Price Control under FaIR Trane Legislation 270 (1939).

For a good summary of the arguments made by proponents of Fair Trade laws, see H.R. ReP. No. 1292, S2d Cong., 2d Sess. 37-40, 44-7, 50-4, 59-61. (1952).

9. One survey concluded that prices increased an average of one-third on Fair Trade items in cut-rate and chain stores after the California Fair Trade Lav was enacted. Grether, Experionce in Califomia aith Fair Trade Legislation Restrieling Price Custing, 24 CALIF. L. REv. 640 (1936).

A more comprehensive survey led to the conclusion that:

"Such figures as are available show almost universally that price-maintained items sell for higher prices than nonmaintained gouds; that prices of contractual articles rose after the law was passed; that prices average higher in cities where maintenance is legal than in comparable cities where it is not legal." TNEC Reporr 194.

Muxd, op. cit. stipra note 8 , at 447 , quotes a 1948 Fortune Ifagazine survey of comparative prices as follows:

"Congressmen and lesser residents of the District of Columbia can lather up with a big tube of Barbasol bought for 29 cents; in fair-trade Mfaryland, the same tube would cost 39 cents. The Congressmen can regenerate the blood calls with Lilly's Lextron Pulvules (\$4's) for $\$ 2.29$, instead of the fair-trade price of $\$ 3.15$. A bottle of Old Granddad is $\$ 5.45$ in Washington, $\$ 6.65$ (before state tax) across the line. BC headache powders are a dime instead of 19 cents.

"A recent study of 117 branded drug items showed that thirty-five cost about a third less in Washington than in Maryland, thirty-eight about a quarter less, and twenty-nine about a seventh less. A comparison of free-trade Missouri and fair-trade Illinois turns 
Fair Trade laws have had a tumultuous history over the last three years. In 1951 they suffered a major setback in the first Supreme Court Schwegemann decision declaring the nonsigner provisions invalid as to commodities in interstate commerce.10 In the following year Congress, under pressure from retailers' and manufacturers' groups, ${ }^{11}$ passed the McGuire Act. ${ }^{12}$ This Act

up much the same story. The St. Louis Star-Times figured out that fifty-four fair-trade drug items cost an average of 16.2 percent more on the east bank of the Mississippi than on the St. Louis side. Fortune Magazine, The Not-So-Fair-Trade Laws, 70 (Jan. 1949)."

For general background on Fair Trade laws, see ZorN \& FeLdusN, Business unden The New Price Laws (1937); Shulman, The Fair Trade Acts and the Laze of Restrictive Agreentents Affecting Chattels, 49 Yale L.J. 607 (1940); Fulda, Resalc Pricc Maintenance, 21. U. OF CHI. L. Rev. 175 (1954).

10. Schwegmann Bros. v. Calvert Distillers Corp., 341 U.S. 384 (1951). For dis. cussion of this case, and the economics of fair trade, see Comment, 61 YALE L.J. 381 (1952).

11. See testimony by Fair Trade exponents before congressional committecs, Hearings before House Committee on Interstate and Forcign Connerce on H.R. 5767, 82d Cong., 2d Sess. (1952). Hearings before Senate Committec on Interstate and Foreign Commerce on H.R. 5767, 82d Cong., 2d Sess. (1952).

The most vigorous advocate of Fair Trade legislation has been the National Association of Retail Druggists. For a description of its successful tactics, see FTC, RepokI" on Resale Price Maintenance 142-66 (1945) (hereinafter cited as FTC Repont).

"The National Association of Retail Druggists prepared and distributed to the state associations a Fair Trade Manual, pamphlets, and bulletins for use in promoting such legislation....

"The national association also, through its Washington representative, formcd Congressional contact committees throughout the country, appointing key men for each Congressional district. ... These key men were personal friends or acquaintances of National and State legislators and Governors of States." Id. at 154.

Twenty-one states adopted the model Fair Trade Act drafted by the NARD. Id. at xxviii.

Consumer groups, on the other hand, have been slow to organize. During Congressional debate before passage of the McGuire Act, Senator Douglas condemned the bill as special interest legislation which would take money out of consumers' pockets:

"However, that money will be slowly taken away from the American people; and since it will be taken away in only small quantities from any one person, the consumer will not know about it, will not protest, will not be articulate, and will not be organized....

"[I]t is an extremely hazardous thing politically for one to take the floor of the Senate and oppose this bill. In a given state, only a few consumers will know the issues involved, or will particularly care. ... But the special interests supporting the bill will be deeply concerned and will resent our action... .

"So here is a very classic case of a diffused general interest coming into conflict with a powerful and concentrated interest." 98 CoNG. REc. 8882-3 (1952) (emphasis added).

12. 66 Stat. 631, 15 U.S.C.A. $\$ 45$ (Supp. 1952). The McGuire Bill was passed overwhelmingly, 196 to 10 in the House, and 64 to 16 in the Senate. 98 CoNG. Rec: 8891 (1952). It amends $\S 5$ of the Federal Trade Commission Act and reads as follows: "Section 5(a) of the Federal Trade Commission Act, as amended, is hercby amended to read as follows:

"Sec. 5. (a)....

"(2) Nothing contained in this Act or in any of the Antitrust Acts shall render un- 
specifically exempts price fixing under Fair Trade nonsigner provisions from federal antitrust laws, ${ }^{13}$ and declares that Fair Trade agreements do not unlawfully burden interstate commerce. ${ }^{14}$ Thts the McGuire Act, while perpetuating the earlier Miller-Tydings prohibition against "horizontal" price fixing, ${ }^{15}$ erases the effect of the first Schacegmann decision and restores limited immunity to Fair Trade operations. ${ }^{16}$

lawful any contracts or agreements prescribing minimum ur stipulated prices, or rcquiring a vendec to enter into contracts or ayrements prescribing minimam or stipulated prices, for the resale of a commodity which bears, or the label or container of which bears, the trade-mark, brand, or name of the producer or distributor of such commodity and which is in free and open competition with commodities of the same general class produced or distributed by uthers, when contracts ur agreements of that descriptiun are lawful.... in any State, Territory, or the District of Columbia. ...

"(3) Nothing contained in this Act or in any of the Antitrust Acts shall rencier unlawful the exercise or the enforcement of any right ur right of action created hy any statute, .... which in substance provides that wilfully and knowingly advertising, offering for sale, or selling any commodity at less than the price or prices prescribed in such contracts or agreements whether the person so aderertising. offering for salc, or selling is or is not a party to such a contract or ayrement. is unfair competition and is actionable at the suit of any person damaged therebs:

"(4) Neither the making of contracts or agreements as described in parayraph (2) of this subsection, nor the exercise or enforcoment of any right or right of action as descriled in parayraph (3) of this subsection shall constitute an malaceful burden or restraint upon, or interference with, commerce.

"(5) Nothing contained in paragraph (2) of this subsection shall make lawful contracts or agreements providing for the establishment or maintenance of minimum or stipulated resale prices un any commodity referred $t o$ in paragraph (2) of this subsection, between manufacturers, or between producers, or between wholesalers, or between brokers, or between factors, or between retailers, or between persons. firms, or corporations in competition with ea:h uther."

Important innovations made by the McGuire Act, in comparison with the earlier Miller-Tydings Act, are italicized.

13. See statute $\$ 5(a)(2)$ and (3), note 12 supra.

14. See statute $\S 5(\mathrm{a})(4)$, note 12 supra.

15. See statute $\$ \overline{5}(\mathrm{a})(5)$, note 12 supra. Both the Miller-Tydings and the McGuire tcts expressly forbid price fixing agreements between competiturs on the same distributive level. And the spousors of the act stated that it would permit only "vertical" price fixing (agreements hetween persons un different levels, i.g., a manufacturer and a retailer). H.R. RFir. Nis. 1437, 82d Cong., 2d Sess. 3 (1952).

16. The Congressimal sponsurs forthrightly declared that the bill's purpose was to uverrule the Supreme Cuurt. See H.R. Rep. No. 1437, 82d Cong., 2d Sess. 1-2 (1952).

By way of contrast, the Canadian Parliament, on December 29, 1951, made resale price maintenlance agreements illegal. The bill was sponsored as an anti-inflationary measure. The sponsor uf the bill hacl commented: "I find it very difficult . . . to escape one conclusion, and that is that many of those engaged in the business of producing and distributing in this country have one great ambition in common, and that is a desire to escape from or minimize the possibilities of present and future competition." The Canadian report uf the Ruyal Commission un Prices had reported: "IV conclude that the adzantuge's to the pulicic claim, for this practice are greatly outweighed by the disadvantages." Hearings lefuer Senate Committec on Interstate and Foreign Commerce on H.R. Sio $82 d$ Cong., du sess. 18-19 (1952) (emphasis added). 
This lesililative victory for Fair Trade did not long go unchallenged. Both the Heliuire Act and state Fair Trade statutes were attacked in the courts on constitutional grounds, ${ }^{17}$ and new claims that Fair Trade practices resulted in horizontal price fixing were advanced before administrative agencies. ${ }^{18}$

The recent case of Schwegmann Brothers Giant Supermarkets v. Eli Lilly $\therefore \mathrm{Co}^{13}$ raised the constitutional issues. Lilly, a drug manufacturer, sued schwegmann Brothers, retailers, to enjoin them from selling Fair Trade commodities below the retail prices fixed by Lilly. ${ }^{20}$ Schwegmann Brothers couintered by attacking the constitutionality of the Louisiana Fair Trade Act ${ }^{21}$ as made operative by the McGuire Act. Three grounds were urged: that the law is insufficiently related to the public welfare to come within the police power of the state; that it imposes an unlawful burden on interstate commerce; and, primarily, that it is an unconstitutional delegation of price fixing power to private persons. ${ }^{22}$

Denial of certiorari by the Supreme Court ${ }^{23}$ left intact the majority opinion of the Fifth Circuit ${ }^{24}$ upholding the district court's injunction against Schwegmann. ${ }^{25}$ The Fifth Circuit felt that the 1936 Supreme Court decision in Old Dearborn Distributing Co. $v$. Seagram-Distillers Corp. ${ }^{26}$ which held the

17. Schwegmam Bros. v. Eli Lilly \& Co., 205 F.2d 788 (5th Cir. 1953), cert. denied, $7+$ Sup. Cit. 71 (1953). Sumbeam Curp. v. MacMillan, CCH Trade Reg. Rep. $\{67,451$ (D. Md. 1953); Sunbeam Corp. v. l'ayless Drug Stores, CCH Trade Re(. Rep. I67,492 (C.D. Calif. 1953).

Two state courts have held acts invalid under their state constitutions. Liquor Store, Inc. v. Contineutal Distilling Corp., to So.2d 371 (Fla. 1949); Shakespeare Co. v. Lippman's Sporting Goods Co., 334 Mich. 109, 54 N.W.2d 268 (1952). The Georgia court held that the legislature nust re-enact new legislation after the McGuire Act in order to wercume earlier constitutional ubjections. Grayson-Rubinson Stores, Inc. v. Oneida, Ltd., 209 Ga. 613, 75 S.E.2d 161 (1953), cert. denied, 7t Sup. Ct. 39 (1953). The Tennessee cuurt has rendered Fair Trade unenforceable in that state until a clear-cut ruling on constitutionality has been delivered hy a federal cuurt, preferably the Supreme Court. Calvert Distillers Curp. v. Ribilio, CCH TRade Reg. Rep. \ 67,540 (Tenn. 1953).

18. In $r$ C Doubleday \& Cu., CCH TRAdE REG. ReP. I 11,515 (FTC 1953) ; In re East-

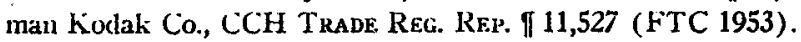

19. 205 F.2d 788 (5th Cir. 1953), cert. denied, 74 Sup. Ct. 71 (1953).

20. Schwegmam Brothers were sued for selling a bottle of Lilly's insulin for $\$ 2.08$, whereas Lilly's Fair Trade price was $\$ 2.83$. Schwegmann Brus. v. Eli Lilly \& Co., 205 F.2d 788, 793 (5th Cir. 1953).

Scliwegmann neither sold merchandise beiow cost nor employed "loss leaders." The uncontradicted evidence indicated that Schwegmann made a profit of from 10 to $15 \%$ un Lilly's products, as compared with 35 to $40 \%$ available under Fair Trade prices. Eli Lilly \& Co. v. Sehwegmann Brus., 109 F. Supp. 209, 270 (E.D. La. 1953).

21. 27 LA. STat. Axx. tit. 51 , $\$ \$ 391-6$ (1951). See note 6 supra for excerpt from the critical nonsigners" provision.

22. Schwegmann Brus. v. Eli Lilly \& Cu., 205 F.2d 788, 790-1 (5th Cir. 1953).

23. 74 Sup. Ct. 71 (1953).

24. Schwegmann Bros. v. Eli Lilly \& Cu., 205 li.2l 788 (jth Cir. 1953).

25. Eli Lilly \& Cu. v. Sihwegmann Bros., 109 F. Supp. 269 (E.D. La. 1953).

2u. zi:y U.S. 183 (1930). 
Illinois Fair Trade Act constitutional, was controlling. ${ }^{27}$ Both the district court and the Fifth Circuit dissent questioned Old Dearborn and urged its reconsideration. ${ }^{2 s}$

Although Schwegmann's first two arguments are probably insubstantial, $=3$ the third contention poses serious questions. In the Old Dcarborn case, the Court, through Mr. Justice Sutherland, touched but lightly on the charge of unconstitutional delegation of price fixing authority. Mir. Justice Sutherland held that the retailers had consented in advance to price fixing by accepting goods already trademarked. ${ }^{31}$ But this "consent in advance" reply is unsatisfactory. As the Supreme Court itself pointed out in the first Sclicugmann case, Fair Trade laws rest upon coercion rather than consent, for the enjoined nonsigning retailer has clearly rejected the arrangement.31 Moreover, the

27. Schwegmann Bros. v. Eli Lilly \& Co., 205 F.2d 788, 792 (1953).

28. "In other words, it may well be found that the real purpuse of fair trade legislation is to protect the retailer from comptition with another retailer why, bseause of his efficient merchandising methods, is able to reduce his distributive costs and consequently his retail prices. This is a matter, hoa'cero, which addresses itself to the Sifprene Court." Eli Lilly \& Co. v. Schwegmann Bros., 109 F. Supp. 269, 272 (E.D. LI 1953) (emphasis added). These views of the district judge were endorsed by Judge Holmes in his dissent to the Fifth Circuit decision, 205 F.2d 788, 793-8 (1953).

29. The Supreme Court has consistently refused to invalidate economic legislation as being beyond the state's police power. Olsen v. Nebraska, 313 U.S. 236 (1941); West Coast Hotel Co. v. Parrish, 300 U.S. 379, 399 (1937) : Nebbia v. New Yorl, 291 U.S. 502, 537-S (193t).

The Supreme Court has been equally consistent in holding that congressional puwer over interstate commerce is plenary and that it may exercise that power ly permitting states to regulate designated phases of interstate commerce. Prudential Insurance Co. v. Benjamin, 328 U.S. 108 (1946) : International Shw Co. v. State of Washington, 326 U.S. 310, 315 (1945).

30. Old Dearborn Distributing Curp. v. Seagram-Distillers Corp., 299 U.S. 183, 194 (1936). Only the trademark seemed to distinguish this delegatiun from the une outlawed in Carter v. Carter Coal Co., 298 U.S. 238 (1936), where the Court had said: "[I]n the very nature of things, one person may not be entrusted with the power to regulate the business of another, and especially of a comptitor. And a slatufe sohish affempls to confer sizch pourer undertakes an intolerable and unconstitutional interfercnec sith personal liberty and prizate preperty:" Id. at 311 (emphasis added).

Throughout the Old Dcarhum decision the Court, through Mr. Justice Sutherland, emphasized the good will involved in a trademark, stating that the "primary aim of the law is to protect the property-namely, the gord will-ui the producer, which he still owns. The price restriction is adopted as an appropriate means to that perfectly legitimate end, and not as an end in itself." Old Dearborn Distributing Curp. v. SeagramDistillers Corp., 299 U.S. 183, 193 (1936). This classic statement is a questionable premise in light of the circumstances surrounding the passage of the legislation. Nute, 49 Yale L.J. 145, 146 (1939). Furthermore, the primary purpuse of a trademarli is to prutect the manufacturer's commodity from unstrupulous counterfeiting and copying by other manufacturers. There seems to be little justification in allowing the trademarls to become a vehicle for price fixing. See Diggins, Trade-Mlarls and Kestraints of Trade, 32 Geo. L.J. 113 (1914).

31. In speaking of Fair Trade laws, the Court said: "That is not price fixing by contract or agreement; that is price fixing by cumpulsiun." Schwegmann Brus. v. Lal- 
"consent" argument fails to meet the basic constitutional challenge: that this delegation of authority to private, interested parties-manufacturers-to fix prices is unconstitutional. It is no answer to say that another group of private, interested parties-retailers - has consented to the price fixing; a delegation of its authority by a state, if unlawful, cannot be ratified and made lawful by a private group. ${ }^{32}$

The Old Dearborn decision and the denial of certiorari in the second Schruegmann case thus leave a vital question unresolved. Plenary power to fix prices, when delegated to private groups, has a serious impact on the consuming public. ${ }^{33}$ Since the Supreme Court has never squarely faced the Fair Trade delegation question, its denial of certiorari in the second Schwegmann case constitutes an unfortunate exercise of judicial discretion..$^{34}$

With constitutional challenges temporarily quieted, ${ }^{35}$ only one effective bar to unrestrained Fair Trade activities remains : the McGuire Act proviso against

vert Distillers Corp., 341 U.S. 384, 388 (1951). The Court further characterized enforcement against nonsigners as "a program whereby recalcitrants are dragged in by the heels and compelled to submit to price fixing." Id. at 390 .

32. Thus the delegation involved here would seem clearly to be more objectionable than that outlawed in Carter v. Carter Coal Co., 298 U.S. 238 (1936), and Schechter Poultry Corp. v. United States, 295 U.S. 495 (1935), where the legislation provided for ratification by an agency or official of the Government. See Note, 50 HAnv. L. REv. 667 (193\%).

33. When prices are determined by private parties rather than by public representatives, there exists a strong tendency to charge all that the traffic will bear. See concurring opinion of Mr. Justice Douglas in United States v. Line Material Co., 333 U.S. 287, 320 (1948). In this case, the Supreme Court outlawed a cross-licensing and license pooling arrangement which gave private parties the power to fix prices.

The impact of this price fixing power is made more serious by the lack of public hearings or public supervision as to the reasonableness of the prices fixed. In Fashion Originators' Guild of America, Inc. v. FTC, 312 U.S. 457, 465 (1941), the Court condemned "an extragovernmental agency, which prescribes rules for the regulation and restraint of interstate commerce."

The doctrine that price fixing is strictly a governmental function was originally developed by Mr. Justice Peckham. United States v. Joint Traffic Ass'n, 171 U.S. 505 (1898); United States v. Trans-Missouri Freight Ass'n, 166 U.S. 290 (1897).

34. Of course, the court's denial of certiorari cannot be interpreted as a decision on the merits, although jubilant Fair Traders were so inclined. See full page advertisement by Doeskin Products, Inc., praising the "nine men of wisdom." N.Y. Times, Oct. 22, 1953 , p. 44.

35. Despite the Old Dearborn decision, state Fair Trade Acts are not universally considered constitutional. The highest courts of four states have invalidated state legislation within the last three years. See note 17 supra. In addition, a lower New Jersey court has recently declared the New Jersey Act unenforceable. Lionel Corp. v. GraysonRobinson Stores, Inc., 98 A.2d 623 (N.J. Super. 1953). Further constitutional challenges have been made in other states. See CCH Trade Reg. Rep. Iff 67,366 (Ore. 1953), 67,379 (III. 1953), 67,381 (Md. 1953), 67,443 (N.Y. 1953), 67,462 (N.Y. 1953), 67,498 (Wash. 1953) ; Cal-Dak Co. v. Sav-on Drugs, 254 P.2d 497 (Cal. 1953). The Supreme Court's denial of certiorari will no doubt put the quietus on some of this litigation, but the con- 
horizontal price fixing. ${ }^{36}$ In the past. this limitation has been utilized infrequently ; Government enforcement agencies maintain that the "cloalk" of Fair Trade laws makes the necessary proof of conspiracy doubly difficult.j7 But with Fair Trade reinforced by the recent certiorari denial, new attention should be devoted to the illegality of horizontal price fixing.

A recent development within the Federal Trade Commission indicates a possible first step in this direction. In re Doubleday ${ }^{3 B}$ involved a company operating in the dual role of book manufacturer and retailer. Doubleday signed Fair Trade agreements with competing retailers, thereby fixing retail prices. The FTC saw the possibility of horizontal price fixing on the retail level and filed a complaint. ${ }^{39}$ After taking initial evidence, the hearing examiner dismissed the complaint. This action was reversed on appeal to the Commission, which unanimously ordered the hearing to continue. Two commissioners felt that the Doubleday arrangement was prima facie invalid. ${ }^{10}$ Two others, however, thought more evidence was necessary for an ultimate determination of whether Doubleday the retailer, or Doubleday the manufacturer, was fixing prices. ${ }^{41}$ But this decision, together with another announced two weeks later involving almost identical facts, ${ }^{, 2}$ indicates that a manufacturer who also retails may be barred from using Fair Trade agreements to $\mathrm{fx}$ retail prices. While the Doubleday approach to such practices is a new one for the

stitutionality of Fair Trade will probably continue to be a doubtful and much contested question.

36. See note 15 sipra. The only ther available statutory limitation, that the commodities must be in "free and upen competition with commodities of the same general class produced or distributed by others," was applied only once in fifteen years, under similar language in the Miller-Tydings Act. Eastman Kodak Co. v. FTC, 158 F.2d 592 (2d Cir. 1946), cirt. denied, 330 U.S. \$2\$ (1947).

37. "If the Department of Instice had sufficient personnel to cxamine cach contract and the circumstances ander aibich it was chtered info, there is ng doubt that many resale price maintchance agrcenconts would be fousd to be violatize of the antitrust lozes. Lacking personnel sufficient to make the investigations necessary to develop cases showing such violations, we can only appeal to the Congress to remove the cloal: bchind which the violators hide." Statement of $\mathrm{H}$. G. Morison, Assistant Attorney General in charge of the Antitrust Division, U.S. Dep't Justice, Hcarings before House Subronmiltec on Interstate and Foreign Commere on H.R. 576r, 82d Cong., 2d Sess. 253, 259 (1952) (emphasis added). The FTC also concluded that Fair Trade laws provide undesirable protection for illegal price fixers. FTC Report L-Lvi.

38. CCH TRade REg. Rep. II 11,515 (FTC 1953).

39. Since Doubleday was a retailer, and fixed prices with other retailers, the agreements were between competitors on the same distribution level. Ilbid.

40. Commissioners Carretta and Spingarn took this view. Ibid.

41. Chairman Howrey and Commissioner Mead thus felt that the hearing examiner did not reach "the ultimate question for decision." Ibid.

42. The factual situation of In re Eastman Kodal Co., CCH Trans REo. Rer. I11,527 (FTC 1953), was similar. Eastman operated both as a manufacturer and retailer, and fixed all retail prices by Fair Trade contracts. Commissioner Mason, who had not participated in the Doubleday case, joined in the majority decision that the complaint stated a cause of action. Chairman Howrey dissented, and Commissioner Mfend did not participate. 
FTC,33 it is based on established precedent: the Supreme Court has in the past prohibited manufacturers from joining into horizontal arrangements, on either the wholesale or retail level.44

The impact of the Doubleday interpretation may be significant; a considerable number of Fair Trade manufacturers also operate retail outlets. ${ }^{45}$ And an even greater number act as wholesalers by selling direct to retailers, while signing Fair Trade contracts with competing wholesalers, ${ }^{40}$ thereby fixing wholesale prices. Under Doubleday's rationale, these arrangements would also be condemned as containing the prohibited horizontal price fixing element.

Nor are the potentialities of the McGuire Act proviso limited to situations where the manufacturer plays a double role. Fair Trade practices which are even more widespread also smack of horizontal price fixing conspiracy. First, Fair Trade in operation encourages horizontal price fixing on the manufacturing level: two manufacturers may not lawfully agree to fix prices, but they can accomplish the same result indirectly by adopting identical "vertical" price structures. ${ }^{47}$ Since Fair Trade sanctions vertical agreements, the temptation

43. The possibility of the Doubleday approach has been foreseen for some time But, until the present, such arrangements were considered safe. See Williams, Resale Price Maintenance and Minimum Price Legislation in INSTJTUTe on ANTITRUST LAWS AND Minimum Price Legislation 141, 153 (1950); 1 Callmann, Unfair Competition AND TRADE-Marks 461 (1950).

44. United States v. Frankfort Distillers, Inc., 324 U.S. 293 (1945) (manufacturers joined with certain retailers to pressure other retailers into fair trade arrangements); United States v. Bausch \& Lomb Optical Co., 321 U.S. 707 (1944) (manufacturer cooperated with both retailers and wholesalers to fix prices).

45. See Phillips, Marketing by Manufacturers 144 (1946); Zorn \& Feldman, Business under the New Price Laws 12-13 (1937).

46. See Phillips, Marketing by Manufncturers 145-57 (1946). According to the United States Bureau of Census, $28 \%$ of total sales in 1948 were made by manufacturcrs direct to retailers. 4 Census of Business 12 (1952). Of course, further analysis would be required to determine the use of this distribution method for commodities which are sold under Fair Trade price fixing agreements.

47. Such use of resale price maintenance is illustrated by figures for one industry's minimum resale prices in FTC REPORT 542 :

ITEM

Absorbent Cotton:

1 pound Carton

$1 / 2$ pound Carton

$\pi / 4$ pound Carton

Adhesive Tape:

$1 / 2$ inch by 5 yds.

1 inch by 5 yds.

2 inches by 5 yds.

Ganze Bandage:

1 inch by 10 yds.

$1 \mathrm{I} / 2$ inch by $10 \mathrm{yds}$.

2 inch by 10 yds.

3 inch by 10 yds.

4 inch by 10 yds.

Surgical Gauze, 36 inches by 10 yds.

\begin{tabular}{ccr}
\multicolumn{3}{c}{ MinimuM Retall PucE } \\
$\begin{array}{c}\text { Johnson \& } \\
\text { Johnson }\end{array}$ & $\begin{array}{c}\text { Baner } \\
\text { Black }\end{array}$ & $\begin{array}{r}\text { Parke- } \\
\text { Davis }\end{array}$ \\
$\$ 0.69$ & $\$ 0.69$ & $\$ 0.69$ \\
.37 & .37 & .37 \\
.23 & .23 & .21 \\
& & \\
.10 & .10 & .10 \\
.19 & .19 & .19 \\
.33 & .33 & .33 \\
& & \\
.05 & .05 & .05 \\
.08 & .08 & .08 \\
.10 & .10 & .10 \\
.14 & .14 & .14 \\
.19 & .19 & .19 \\
.49 & .47 & .49
\end{tabular}


to set identical prices would seem irresistible, especially where the manufacturers are few in number. ${ }^{48}$ In this manner, resale price maintenance can become a tool for eliminating price competition between competing brands. It is therefore not surprising that Fair Trade is used most effectively in industries dominated by only a handful of manufacturers. ${ }^{\text {to }}$ Where such agreements between retailers and oligopoly manufacturers exist, the horizontal price fixing proviso should be revitalized. When Fair Trade manufacturers consistently fix identical resale prices, there is circumstantial evidence of conspiracy. ${ }^{50}$ If the doctrine of conscious parallel action is invoked, as it should be, such practices could be struck down under both the Sherman and Federal Trade Commission Acts. ${ }^{51}$ In this way, Fair Trade activities could be brought within their legal limits, and at least limited competition among manufacturers could be restored for the consumer's benefit.

Fair Trade, moreover, facilitates horizontal price hixing among retailers.:2 It encourages them to operate through powerful trade associations to coerce

48. "In the operation of resale price laws, there is a tendency for varivus manuiacturers-such as those of flour, cereals, scaps, camnd mill, and vegetable shurtenings-to make identical resale price agreements. This procedure serves to eliminate price competition at the manuiacturing level, for all manufacturers will thereup soll to the windesalers or retailers at the same price." $M 1 \times \mathrm{Nm}$ op. cit. suira nute $\mathrm{B}$, at $4 \mathrm{ft}$.

49. "Application of resale price maintenance, especially with respect to stople articles, has been fostered in certain industries where production is largely concentrated in the hands of a few manufacturers. ..." FTC REroBr lvi.

50. "Acceptance by competitors, without previous agreement, of an invitatiun to participate in a plan, the necessary consequence of which, if carried out, is restraint of interstate commerce, is sufficient to establish an unlawful cunspiracy under the Sherman Act." Interstate Circuit v. United States, 306 U.S. 208, 227 (1939).

Without the implied conspiracy doctrine the antitrust laws are ineffective; but if parmitted this essential weapon, they can more properly fulfill their basic functions of maintaining competition and prohibiting market control by powerful special interests. FTC v. Cement Institute, 333 U.S. 683 (1948); American Tobacco Co. v. United States, 333 U.S. 781 (1946); United States v. Aluminum Co. of America, 14S F.2d 416 (2d Cir. 1945). See Rostow, The New Sherman Act: A Positize Instrument of Progress, $14 \mathrm{U}$. of Cul. L. Rev. 567, 574-5 (1947); Levi, The Antitrust Lau's and Monogoly, 14 U. of CnI. L. REV. 153, 183 (1947).

51. In finding a conspiracy under the Sherman Act, courts usually require additional evidence besides the parallel business practices. American Tobacco Co. v. United States, 328 U.S. 781 (1976). Under the Federal Trade Commission Act, on the other hand, the parallel prices in themselves might constitute an unfair method of competition and hence a violation of $\$ 5$, without the necessity of additional incriminating evidence. This latter theory was relied upon successfully by the FTC in Triangle Conduit \& Cable Co. Y. FTC, 168 F.2d 175 (7th Cir. 1948), aff'd per curiam sub nom. Clayton Mark \& Co. v. FTC, 336 U.S. 956 (1949). However, this development was bitterly criticized by many and the future usefulness of the conscious parallelism doctrine is still in doubt. See Kittelle $\&$ Lamb, The Implied Conspiracy Doctrine and Delieered Pricing, $15 \mathrm{LAw}$ \& Costersp. Pros. 227 (1950).

52. "Thenceforward any group of distributors desiring to fix prices horizontally would be foolish to take the direct road to that end. Instead, some one of their number should make a vertical contract with a supplier and then place the other members of the group 
manufacturers into adding new commodities to the Fair Trade list and into raising retail prices to a high level. ${ }^{53}$ In fact, Fair Trade is most effectively practiced where strong retailers' groups exist. ${ }^{44}$ Here again the McGuire Act proviso should be given new force. When retailers band together to extract high Fair Trade prices from manufacturers, a price fixing conspiracy can be found..$^{55}$

In the foregoing situations, traditional doctrines of implied conspiracy can be raised not only by agents of antitrust enforcement but also by nonsigning retailers resisting Fair Trade. Where they can show rigid price parallelism among manufacturers, or concerted coercion from retailers, nonsigners may

on notice of the existence of the contract. Through this means the group could not anly negate the objections of the Government but could actually use the courts as devices to enforce the arrangement." Statement of Everette MacIntyre, Assistant Director, Burcau of Antimonopoly, Federal Trade Commission in Hearings before Scnate Commillec on Interstate and Forcign Commerce, 82d Cong., 2d Sess., 28 (1952) (emphasis added).

53. "In practice, however, resale price maintenance serves as a focal point for dealer cooperative effort to bring pressure to bear on manufacturers to place products under price maintenance at prices yielding dealer margins satisfactory to cooperating organized dealer groups." FTC Report liv.

"Lack of adequate enforcement of the antitrust laws [caused by Fair Trade exemptions] leaves a broad field for the activities of organized trade groups to utilize it for their own advantage and to the detriment of consumers." Id. at lxi. See Fulda, Resalc Price Haintenance, 21 U. of CHr. L. Rev. 175, 192-3 (1954).

54. "Pertinent in this connection is the fact that so-called fair trading has been most successful in those fields where strong trade associations exist. Trade associations . . . can spread the fair-trade net over both retailers and manufacturers." Statement of H. G. Morison, Assistant Attorney General in charge of the Antitrust Division, U.S. Dep't Justice in Hcarings before House Subcommittee on Interstate and Forcign Comnerce on H.R. 5767, 82d Cong., 2d Sess. 256 (1952). "[P] ressure from distributors creates a strong resemblance to horizontal price fixing. The druggists, through their State and National associations, decided that they needed a 50 percent mark-up on invoice prices. This comes close to horizontal action, although it is taken through the medium of an association. Moreover, such pressure exerted simultaneously on competing manufacturers reinforces the tendency toward identical prices at the production level. Horizontal price fixing may not exist in name, but it is closely approached in fact." TNEC REponT 196.

In this connection, the following observation by the district court judge in the second Schwegmann case is significant:

"The affidavits in evidence taken from retail druggists show that unless the fair trade price on plaintiff's products is protected, the retail druggists will stop selling plaintiff's products and favor products of plaintiff's competitors." Eli Lilly \& Co. v. Schwegmann Bros. Giant Super Markets, 109 F. Supp. 269, 272 (E.D. La. 1953). This conduct would seem to indicate evidence of concerted action among retailers.

55. See 1 Callamann, Unfair Competition and Trade-Marks 509, n.62 (1950). Heretofore no serious efforts have been made by the Government to discourage organized combinations among Fair Trade retailers, because of an alleged lack of personncl and funds. See notes 37, 53 stpra. However, the Stupreme Court has approved governmental limits on the activities of trade associations in other contexts. See, c.g., Sugar Institute, Inc. v. United States, 297 U.S. 553 (1936) ; United States v. American Linseed Oil Co., 262 U.S. 371 (1923); American Column \& Lumber Co. v. United States, 257 U.S. 377 (1921). 
have a defense to Fair Trade injunction suits. ${ }^{56}$ Several decisions have denied a Fair Trade plaintiff an injunction against a nonsigner on the ground that plaintiff's resale price maintenance system, operating behind a veil of legality, in fact constituted horizontal price fixing. ${ }^{6 \pi}$

Thus, repeatedly disregarded by the legislatures and now unheeded by the Court, the voiceless consumer finds himself still saddled with Fair Trade's higher non-competitive prices. But the constitutional challenges, leit unresolved, may be brought again to the Supreme Court. Meanwhile the MicGuire Act provides a leaky umbrella for price fixers: new efforts to revitalize the Act's proviso would discourage the extensive horizontal price fixing practice now flourishing in the shelter of Fair Trade Laws.

56. See 1 Callmaxx, Cifair Conpetrtion and Trane-Marks 497 (1950): Locli= hart, Violation of the Antitrust Law's as a Defense in Cisil Aitions, 31 Mrats. L. Row. 507, 563-8 (1947).

The other, more standard defense available to nonsigners involes the equitable "clean hands" doctrine. In order to obtain an injunction, the manufacturer must be diligent in his enforcement program, and shuw no favoritism or discrimination. Fogel v. Bolet, 194 MIisc. 643, 87 N.Y.S.2d 471 (Sup. Ct. 1949) ; Calvert Distillers Corp. v. Nussesum Liquor Store, Inc., 166 Misc 342, 2 N.Y.S.2d 320 (Sup. Ct. 1938). Thus if the nonsigner an show widespread undercutting of the fixed price, he has established his defense. Magazine Repeating Razor Co. v. Weissbard, 125 N.J. Eq. 593, 7 A.2d 411 (Ch. 1939). This defense was attempted, unsuccessfully however, in General Electric Co. v. R. H. Mlacy \& Co., 199 Misc. 87, 103 N.Y.S.2d 440 (Sup. Ct. 1951).

57. Schill r. Remington-Putnam Eook Co., I\&2 MId. 153, 31 A.2d 467 (1943) (Fair Trade agreements fixing retail prices of books held illegal and unenforceable); Pazen $v$. Silver Rad Stores, Inc, 130 X.J. Eq. 407, 22 A.2d 237 (Ct. Err. \& App. 10.41) (Fair Trade agreement fixing retail price of cigarettes held a "hurizontal contract" and thus void; injunction dismissed by unanimous court); Rayess v. Lane Drug Co., 138 Ohio St. 401, 35 N.E.2d 447 (1941) (Fair Trade agreements fixing retail prices of cigarettes found to be a "horizontal" arrangement, and hence unenforceable against a nonsigner). 